\title{
PERBEDAAN PENYESUAIAN SOSIAL MAHASISWA DILIHAT DARI POLA ASUH ORANG TUA
}

\author{
Lidya Wati, Hasgimianti \\ Uin Suska Riau \\ Hasgimianti@uin-suska.ac.id
}

\begin{abstract}
ABSTRAK: Penelitian ini bertujuan untuk mengetahui bagaimana pola asuh orang tua. Perkembangan sikap anak tergantung dari bagaimana cara didikan orang tua terhadap anak. Oleh sebab itu pola asuh orang tua sangatlah penting bagi anak, selain itu pun pola asuh orang tua juga merupakan salah satu factor bagaimana anak bersikap atau bertingkah laku di lingkungan sekitarnya. Dalam penenlitian ini menggunakan desain korelatif yang dilihat di lingkungan UIN SUSKA. Hasil penelitian ini di dapatkan dari melalui penyebaran angket, yang disebarkan ke 30 mahasiswa di UIN SUSKA. Hasil penelitian menyebutkan bahwa penyesuaan diri yang negative berupa berpacaran sebanyak 21 mahasiswa (70). Hal itu berada pada Klasifikasi Tinggi. Sedangkan Klasifikasi Sedang sebanyak 9 mahasiswa $(30)$.
\end{abstract}

Kunci : Penyesuaian Sosial, Pola asuh

\section{PENDAHULUAN}

Pola asuh yang diberikan orang tua juga memiliki dampak pada anak ketika ia sudah mulai beranjak remaja atau mulai dewasa. Pola asuh yang baik maka akan mempermudah anakuntuk bergauk dengan lingkungan sekitar. dan anak tersebut juga akan mudah dalam baradaptasi. Sehingga hal ini juga memudahkan anak dalam berteman dam mengembangkan potensi yang ia miliki. Pola asuh otoriter adalah pola asuh yang yang menekan anak atau tidakmterlalu memberikan ruang gerak pada anak. Menurut Stewart dan Koch (dalam Tarmudji, 2001), pola asuh terbagi kedalam tiga bagian, yaitu pola asuh otoriter, pada pola asuh ini orang tua memiliki sikapkaku, tegas, pemarah, memberikan hukuman, kurangnya rasa percaya kepada anak dan jarangnya memberikan pujian kepada anak. Pola asuh demokratif yaitu orang tua selalu memberikan perhatian, mendengarkan keluh kesah anah, selalu berbicara kepada anak dan mendengarkan pendapat anak. Pola asuh permisif adalah pola asuh yang terlalu memberikan kebebasan terhadap anak sehingga buat ia merasa bebas melakukan apaun dan bertindak sesuka hatinya. Dalam penelitian ini akan dibahas pola asuh orang tua yang otoriter dan demokratif.

Menurut Hurlock (1980) menjelaskan penerapan pola asuh otoriter sebagai disiplin orang tua secara otoriter yang bersifat disiplin tradisional. Pemikiran orang tua selalu merasa takut atau kurang percaya kepada anak membuat anak sulit melakukan apa yang ia mau dan 
tidak jarang anak yang mengalamim pola asuh otoriter terkadang suka malu atau suka mnyendiri bahkan terkadang dia merasa tidak percaya diri dengan dirinya sendiri.

Permasalahan yang sering muncul akibat pola asuh otoriter ini adalah anak sulit untuk mengemukakan pendapat, bergaul, menutup diri, kurang percaya diri, agresif dan takut. Contohnya ketika di dalam kelas anak jarang memngemukakan pendapat yang miliki, ragu-ragu, sulit beradaptasi. Akan tetapi pola asuh otoriter juga memiliki dampak yang baik bagi anak yaitu anak akan patuh akan printah atau peraturan yang ditetapkan, mengerjakan tugas tepat pada waktunya, dan disiplin.

Pola asuh demoktratis adalah orang tua selalu memberikan kepercayaan kepada anak, mendengarkan, dan memberikan kebebasan namun tetap dalam pantauan orang tua. Anak akan mudah bergaul, berteman dan dapat berintraksi dengan baik terhadap lingkungan sekitar. Anak yang mendapatkan pola asuh ini akan cenderung aktif, kreatif dan enovatif.

Namun menurut pendapat sebagian mahasiswa ia mengalami pola asuh otoriter hanya ketika ia berusia remaja atau masa sekolah. Ketika ia masuk kuliah ia diberikan kekebasan oleh orang tua namun tetap dalam pantauan orang tua. Disini orang tua lebih percaya dengan dirinya.

Tujuan umumpenelitian ini adalah untuk melihat bagaimana perbedaan pola asuh orang tua yang otoriter dan demokratif, manakah yang lebih bagus diterapkan.

\section{METODE PENELITIAN}

Dalam penelitian ini peneliti menggunakan desain korelasi yang bertujuan untuk menggunakan hubungan korelatif antar variable. Menurut Raja (2017). Pada penelitian ini alat pengumpul data yang digunakan adalah Skala Likert (angket). Skala ini dimaksudkan untuk mengukur sikap individu dalam dimensi yang sama dan individu tersebut menempatkan dirinya kearah satu kontinuitas item pernyataan. Bentuk tes pada skala Likert adalah pernyataan, alasannya karena yang mengisi angket hanya perlu merespon.

\section{HASIL DAN PEMBAHASAN}

\section{Hasil Uji Validitas dan Uji Realibilitas}

Hasil angka Validitas untuk skala penyesuaian sosial dan pola asuh orang tua terendah adalah 0,720 . Sedangkan, hasil uji realibilitas yang telah dilakukan oleh peneliti didapatkan bahwa koefisien realibilitas untuk skala likert adalah 0,371. Menurut Hartono (2004) apabila $\mathrm{r}$ hitung ( $\mathrm{r}$ alpha $>0,600)$ maka instrument tersebut dinyatakan reliable.

Arikunto (1982) menambahkan: tingkat realibilitas instrument bisa dilihat dari $\mathrm{r}$ hitung ( $\mathrm{r}$ alpha) dengan kriteria sebagai berikut:
a. $0,800-1,00$
berarti sangat tinggi
b. $0,600-0,799$
berarti tinggi 

c. $0,400-0,599$
berarti cukup
d. $0,200-0,399$
berarti rendah
e. $<0,200$
berrti sangat rendah

Hasil tersebut menandakan bahwa skala penyesuaian sosial dan pola asuh orang tua memiliki koefisien realibilitas yang reliabel dan cukup dapat dipercaya untuk digunakan sebagai alat pengumpul data dalam pnelitian ini.

\section{HASIL PENELITIAN}

Pandangan Pola Asuh Orang Tua pada mahasiswa-mahasiswi UIN Suska Riau sebagai berikut:

\begin{tabular}{|c|c|c|c|}
\hline Klasifikasi & Interval & Frekuensi & \% \\
\hline Sangat Tinggi & $88-104$ & 0 & 0 \\
\hline Tinggi & $71-87$ & 21 & $70 \%$ \\
\hline Sedang Tinggi & $54-70$ & 9 & $30 \%$ \\
\hline Kurang Tinggi & $37-53$ & 0 & 0 \\
\hline Rendah & $20-36$ & 0 & 0 \\
\hline
\end{tabular}

Berdasarkan tabel di atas terdapat lebih dari setengah Mahasiswa-mahasiswi UIN SUSKA RIAU dari sampel penyesuaan diri yang negative berupa berpacaran sebanyak 21 mahasiswa (70). Hal itu berada pada Klasifikasi Tinggi. Sedangkan Klasifikasi Sedang sebanyak 9 mahasiswa (30).

'Menurut Elizabeth B. Hurlock (1980), pola asuh orang tua adalah cara orang tua dalam mendidik anak. Sedangkan menurut Chabib Thoha, pola asuh orangtua berarti cara yang dilakukan orangtua dalam mendidik anaknya sebagai bentuk tanggung jawabnya kepada anak. asuh, yaitu:

Sedangkan menurut teori yang telah dikemukan oleh Baumrind ada tiga macam pola

\section{Pola asub Otoriter}

Menurut Baumrind, Bentuk pola asuh otoriter memiliki ciri-ciri yaiu memperlakukan anaknya dengan tegas, suka menghukum anka yang dianggap tidak sesuia dengan keinginan orang tua, kurang kasih saying, dan kurang simpatik, dan mudah menyalahkan segala aktiitas anak terutama ketika anak ingin berlaku kreatif.

\section{Pola asub Demokratif}

Pola asuh Demokratif mempunyai ciri-ciri yaitu orang tua memberikan baik dan kewajiban anaknya secara seimbang, antar orang tua dan anak saling melengkapi, orang tua yang menerima dan melibatkan anak dalam mengalami keputusan yang terkait dengan 
kepentingan keluarga, mempunyai tingkat pengendalian yang tinggi dan mengharuskan anak-anaknya bertindak pada tingkat intelektual dan sosial sesuai usia dan kemampuan mereka, tetapi mereka tetap memberikan memberikan kehangatan, bimbingan, dan komunikasi dua arah, orang tua selalu memberikan penjelasan dan alasan atas hukuman dan larangan yang diberikan oleh orang tua dan anaknya yang selalu mendukung.

\section{Pola asuh premisif}

Pola asuh premisif memiliki ciri-ciri yaitu orang tua selalu memberikan kebebasan kepada anak seluas mungkin, anak tidak dituntut untuk belajar memiliki tanggung jawab, orangbtua memberi hak anak sama seperti orang dewasa, dan memberi kebebasan yang seluasnya dalam mengatur dan mengontrol diri sendiri, orang tua tidak hanya banyak mengatur dan mengontrol dirinya sendiri.

Anak dengan pola asuh permisif biasanya dengan orangtua yang keduanya bekerja, sibuk dengan kegiatannya sehingga tidak memiliki waktu untuk mendiidik anak dengan sebaik-baiknya (Gunarsa, 1986).

\section{KESIMPULAN DAN SARAN}

Masa anak-anak akhir merupakan peralihandari masa anak menuju masa pubertas oleh karenanya harus dipersiapkan secara fisik maupun psikologisnya. Permasalahan terjadi karena pola asuh yang diterapkan orang tua adalah pola asuh otoriter sehingga mempengaruhi perkembangan anak termasuk perkembangan kemandirian dan kecerdasan emosinya. Demikian bahwa anak-anak menunjukkan

perilaku kemandirian yang rendah dan kecerdasan emosi yang rendah pula didukung oleh perilaku yang ditunjukkan oleh orang tua mereka yang bersikap otoriter. Oleh karena itu peneliti tertarik untuk melakukan penelitian tentang hubungan pola asuh otoriter orang tua dan kecerdasan emosi anak dengan penyesuaian sosial anak.

Pola asuh orangtua demokratis danefikasi-diri secara simultan berlaku sebagaiprediktor kreativitas. Variasi tinggi rendahnya kreativitas dapat dijelaskan melalui tinggi rendahnya penerapan pola asuh demokratis dan tinggi rendahnya efikasi-diri.

\section{DAFTAR PUSTAKA}

Tarmudji, T. 2001. Hubungan Pola Asub Orang Tua Dengan Agresivitas Remaja. Editorial Jurnal Pendidikan dan Kebudayaan Edisi 36

Hurlock. 1980. Psikologi Perkembangan. Jakarta: Erlangga.

Rahima, Raja. 2017. Instrumen BK I. Teknik Non Tes (Teori dan Praktek). Pekanbaru: Cahaya Firdaus

Hartono. 2004. Statistik Untuk Penelitian, Pekanbaru: Pustaka Cipta 
Lidya Wati, Hasgimianti

Arikunto, Suharsimmi. 2002. Prosedur Penelitian Suatu Pendekatan Praktek, Edisi revisi v, Jakarta: Rineka Cipta. 